\title{
Cultivation Management of Pakistani TV Channels with Special Reference to Politics
}

\author{
Dr. Khalid Sultan \\ Assistant professor, Department of Communication Studies College of Applied Sciences, \\ Nizwa, Ministry of Higher Education, Sultanate of Oman \\ E-mail: khalid_sultan.niz@cas.edu.om \\ Dr. Mirza Jan (Corresponding Author) \\ Assistant professor, Department of Mass Communication Gomal University, D. I. Khan, \\ Pakistan \\ E-mail: mirzajan_70@yahoo.com \\ Tel. +92-0966-9280461-730183 \\ Muhammad Imran Khan \\ Lecturer, Department of Mass Communication, Gomal University, D. I. Khan, Pakistan \\ E-mail: mehsud_media@yahoo.com
}

Accepted: July 17, 2012 Published: August 17, 2012

Doi:10.5296/ijhrs.v2i3.2260 URL: http://dx.doi.org/10.5296/ijhrs.v2i3.2260

\begin{abstract}
This cross-sectional survey explores the Pakistani TV channels and cultivation of politics. It discusses the voters' attitude and behavior. There are number of media outlets in Pakistan. Media technology especially TV is the most influential medium that shape the trends of the audience. This time 83 private news channels are working in Pakistan. Cultivation of political thoughts is influenced according to exposure to television. An individual's likelihood of receiving political information is a function of cognitive engagement with politics.
\end{abstract}

Keywords: Cultivation, TV, News Channels, Politics 


\section{Introduction}

Television is a close-up medium and a medium that seems to most readily involve emotions; it is most effective when it is revealing the plights of people. The increase in the number of mass media outlets in Pakistan over the last decade has never managed to provide answers to the general public's concern that they only serve particular political or commercial interests. Though the Pakistani mass media have become more accessible to the citizenry and have also invested more time and resources into enlightening the public on issues of human rights, good governance, democracy and nation-building, they are often accused of avoiding critical issues of public interests and usually allow access only to government officials, their political or commercial 'godfathers' or people who have the power to reward them with gifts.

McQuail (2000) suggests that the main power of the mass media can be summarized as: "attracting and directing public interest; persuasion in matters of opinion and belief; influencing behavior; structuring definitions and realities; conferring status and legitimacy and informing quickly and extensively" (c.f. Burton, 2005:29). Notably, private TV channels in Pakistan have allowed the "dissemination of messages as well as the establishment of contact with people otherwise "removed from centers of administration and influencing individuals cut off from the print media". A great number of Liberians depend on radio news and radio is a major player in the promotion of political participation in the country.

Media technology is in the initial stage for political communication. Political parties run their own websites showing their "achievements, policies, objectives, manifestoes, etc". Religious political parties also established their own websites. "These websites are updated on regular basis and they display the latest statements and activities of their leaders and their viewpoint on different national and international issues and events. These websites played a vital role in the 2008 elections of Pakistan. The workers of the political parties are also using the new media in support of their parties as well as propagation against the opponent parties. You tube is carrying hundred of such videos.

\subsection{Pakistan's Political Scenario}

There is no concept of modern democracy without free and fair elections. Similarly, there is no concept of free and fair elections in the absence of a free mass media. So, democracy, elections and media are indispensable for each other. In Pakistan since its establishment, elections have been conducted with irregular intervals. The brief history of elections in Pakistan gives an insight to the democratic process in Pakistan. The First period of electoral politics in Pakistan's history from 1947 to 68 can be divided into two phases: i) parliamentary phase (1947-58) and ii) presidential phase (1962 to 1969). Introduction of presidential system, Field Marshal Ayyub Khan served as the president of Pakistan. He was forced by circumstances to resign on 25th March 1969, handing over power to Gen Muhammad Yahya Khan, then Commander-in-Chief of Pakistan Army. Zulfikar Ali Bhutto founded Pakistan People's Party ( PPP ) in November 1967 and got successful to raise it to the status of 
national party (Becker \& Raveloson, 2008) and Kennedy (1987). Countrywide protest by Opposition finally led to a political turmoil and imposition of Martial Law by the then Army Chief, General Muhammad Zia-ul-Haq on 5th July, 1977.

\subsection{Situation in Pakistan}

Media in Pakistan is seen tremendous. There was only one state owned TV station in the country. This time 83 television channels licensed by the Government of Pakistan are working. "Single FM Radio station was working until 2002 but now 124 FM radio stations are working under the license of Pakistan Electronic Media Regulatory Authority. Twenty years ago only half dozen English and Urdu newspapers could be seen in the market but now hundreds of newspapers are available in the market among which almost two dozen newspapers can be called as International Standard newspapers. Furthermore, dozens of very high quality magazines are also available in market which attracts specific kind of audience like sports magazines, women's magazines, political journals and general interest magazines etc. In short, Pakistani media got a big development in quantity as well as quality in the last one decade".

Pakistan very strictly observes the media activities. The state owned Pakistan Television can't broadcast even a single line against the Government. Private TV channels are kept under strict observation by the Government Authorities and their broadcast is suspended when they telecast something against the Government policies". According to Riaz, S. (2007), the Government pays huge revenue in shape of advertisements to those TV channels and newspapers who favor the Government policies and the media organizations that don't do this, have to deprive of this money. Ultimately, media organizations support the Governmental policies to get a bigger share of the advertisements revenue. Riaz argues that even the private media organization including newspapers and the television channels most of the time support the governmental policies to get a bigger share of the government advertisements. 'However, with the emergence of a number of media organizations in the country now people have different options to get the latest information and it has become difficult to hide the facts from the public. The workers and agents of the political parties made extensive use of mobile phones and short message service for political communication during the election campaign and the elections.

\subsection{Private TV channels}

It was year 2000, after which many private channels came into view when Pervez Musharaf issued license to them. From then began a new era of electronic media. Before private news channels there was limited access to diverse sources of information and people could not keep abreast with the rapidly growing developments around them it was decided by the government to open up electronic media to the private sector in the country. Soon after, in March 2002, it was decided to set up Pakistan Electronic Media Regulator Authority (PEMRA) with a view to facilitate, license and regulate the growth of electronic media in the private sector. In a short span of five years the country has witnessed a massive spurt in the 
number of TV channels in the private sector which is, unmatched in the South Asian region and perhaps elsewhere. This boom is owed to the government's unequivocal commitment to a free media and the positive role played by PEMRA in facilitating the growth of the electronic media. The unprecedented growth of private channels, cable TV has indeed contributed remarkably in raising the standards of public awareness and literacy.

\section{Statement of the Problem}

People who counteract that the media have been serving the general interest of the public by the increase in their news and public affairs programs especially TV talk shows. They further argue that the increase in public affairs programs geared at cultivating public concerns in issues of national interest has positively impacted popular political participation in Pakistan. Political awareness is very much important for a democratic state and it enables the people to know and safeguard their rights. Private news channels provide this awareness to the people; therefore it has a very important role in strengthening the democratic institutions of the country. So, the need is immense to document an inquiry on the role of the private news channels in creating the political awareness of the viewers. The statement of the present study was" Cultivation Analysis of Pakistani TV Channels with Special Reference to Politics".

\section{Justification for the study}

Pakistan lacks adequate studies on how the various private TV channels are often represented in the media thus leaving the imperative need for the conduct of a comprehensive study to assess the contribution of Pakistani TV channels in the promotion of pluralistic opinions in the country. However, every private TV channel claims to attend to all political groups of the society regardless of social, political and economic status. Understanding the media's actual role in the promotion of diversified opinions means understanding their contributions to participatory democratic Pakistan. Consequently, this study is useful in assessing the performance of the private TV channels, thus putting into perspective the debate mentioned earlier.

\section{Literature Review}

Politicians have learned that the appearance of intimacy or the production of an attractive ethos on television is very helpful to political success. As a result, many public figures have attempted to project as far as possible a personable, warm, or approachable image appropriate for television. Public figures that appear distant, cold, or uncaring on television generally succeed in spite of their appearance

Negrine (1996) advocated that mass media performs three major functions including to link public, their opinion and the government decisions with each other; to create public opinion; and enable the public to participate in the democratic process directly or indirectly. Iyengar \& McGrady (2007) suggested that the mass media provide a forum for candidates and political parties to debate their qualifications for office before a national audience and contribute to informed citizenship by providing a variety of perspectives on the important issues of the day. 
Graber (1976) argued that media not only gives information about daily happenings but it also gives explanation, background understanding and prediction for the future course. Connecting the central functions of the news media to the main characteristics of democratic societies Norris (2000) mentioned that news media act as civic forum to enable pluralistic competition, as mobilizing agent to foster public participation and as watchdog to guard civil liberties and political rights.

Lilleker (2006) contributed the importance of the mass media for the political process in modern democracies to a phenomenon known as delightment in political science. Strohmeier (2004) classifies the possible effects of mass media on their audiences and suggested that they can have an impact on the knowledge, attitudes, and behavior of the recipients. Maurer (2009) argues that television's capacity as a source of political information is overestimated. Peterson et al. (2000) commented that the media has a role to inform the citizens about the competing political parties and their programmes and candidates, and to contribute to the formation of opinion of the electorate. Clancey \& Robinson (1985) while commenting on the role of media as watchdog said that television's role in political campaigns and elections is difficult to overestimate television's significance in the political process carries over to the effects on governing the nation.

A common way to measure political awareness is with a short series of factual questions about politics (Zaller 1992; Price and Zaller 1993; Delli Carpini and Keeter 1996). Iyengar and Kinder (1987, pp. 90-97) find no relationship between political awareness and susceptibility to priming in their laboratory experiments. Kinder 1990; Miller and Krosnick's (2000) laboratory study finds the opposite. While one of these previous studies documents evidence of rally effects with priming (Krosnick and Brannon 1993), when examining the moderating influence of political awareness all focus exclusively on the ordinary priming effect them.

Television encourages coverage that focuses on the personal celebrity of participants and on the sporting elements of political conflict (Fallows, 1996; Postman, 1985). Less politically sophisticated people may lack the cognitive ability to link their personal experiences with the broader political landscape and therefore fail to bring experience to bear on attitude formation (Gomez and Wilson 2001).

\section{Theoretical Framework}

Cultivation analysis focuses on the consequences of exposure to its recurrent patterns of stories, images, and messages. Cultivation analysis is not a substitute for but a complement to traditional approaches to media effects. Traditional research is concerned with change rather than stability and with processes more applicable to media that enter a person's life at later stage (with mobility, literacy, etc.) and more selectively (Gerbner, 1998).

Democracy is about participation and representation. Participation is the extent to which individual members of society take part or get involved in the activities in their societies. 
Representation on the other hand, refers to the process by which people get chosen to act in the interest of the community or sectors thereof. In modern day where the dominant form of democracy is indirect or representative democracy, political parties are the principal mechanism for ensuring citizen participation and representation in public policy decision-making (Agbaje, 2005); and in fact through which individuals share the democratic values.

\subsection{Cultivation Theory}

Cultivation theory explains that how people's conceptions of social reality are influenced according to exposure to television. "The cultivation hypothesis states that the more television people watch, the more likely they are to hold a view of reality that is closer to television's depiction of reality. This is characterized by the work of George Gerbner and his colleagues (Gerbner et al., 1979)" (Zaharopoulos, 2001).

\section{5,2 Assumptions Major tenets of the theory}

Television has become major part of our life. We spend more time watching television than at any other activities except sleep and occupational duties (Comstock, Chaffee, \& Kautzman, 1978; Kubey \& Csikszentmihalyi, 2002). The quantity of time people use watching television is surprising. Gerbner and others claim that those who watch television more have the perception that real world is similar to the world presented in television dramas (Gerbner and Gross, 1976). This phenomenon is highly showed by heavy viewers of television than light viewers.

\subsection{Pluralism as a Political Value}

Pluralism is rooted in liberal democracy. It is also recognized as a universal standard of the press which has become important to mass media theories (McQuail, 1992). But like any political value, pluralism in the media often proves difficult to define. However, generally, it can be construe for a principle of access for all views and voices irrespective of social, economic or political status. For instance, McQuail (1992:144) stresses that pluralism demands that the mass media make available channels through which the separate voices, groups and interests that make up the society can speak to the wider public; and "it is often by this way of access that critical, oppositional and deviant voices, which are essential to change and choice can be heard".

\subsection{Democracy as a Concept}

The concept of democracy has largely remained built around people and power. However, the concept is 'unstable with no fixed definition (Cammaerts, 2007; Buss, Redburn \& Guo, 2006; Louw, 2005; Kuper, 2004; Barber, 1984).

\subsection{Mass Media and Democracy}


One enquiry often sought by media researchers is: whether information released to the people by the media most of the time represent popular need. Cammaerts (2007:161) says information lacks neutrality and the "selection and distribution of information and the related processes by the media has been part of academic scrutiny for decades".

\subsection{TV Channels' Creeping into Pakistani society}

Nothing is hidden in the age of communication revolution. "The media revolution started to creep into Pakistani society in the early years of former President Pervez Musharraf s rule. Former officials associated with General Musharraf s government pointed out that it was an intentional move of the military government to enact new and liberal laws to create operating space for private news channels. But it never would have crossed the former military ruler General Musharraf $\mathrm{s}$ mind that the new forces of media freedom he was unleashing in Pakistani society would turn against him and would ultimately lead to his removal from government." General Musharraf was of the opinion that Pakistani news channels would pull the Pakistani public away from watching Indian news channels, a habit that was harming the country's national interests badly," said a retired official associated with Musharraf s presidency.

\section{Research Questions}

1. Whether viewer pays attention to TV talk shows?

2. Does public opinion prevailing statement against war on terror?

3. Do media create political awareness?

\section{7, METHODS}

The design of the present study was a cross-sectional survey. The demand of this study was to collect information from the field. The population of the study was the main city of district Dera Ismail Khan (KPK) Pakistan. This area is not much facilitated with modern technology of Communication. The sample of this study was the voters of city. The sample size of the study is 250 residents and method of the sampling for this particular study is systematic sampling and every $5^{\text {th }}$ house has been selected for getting information.

\subsection{Procedure}

A pilot study was conducted before the distribution of questionnaire among the voters. Twenty five voters were randomly selected for the pilot testing. The main purpose of the pilot study was to give a clause for putting observations. After placing of the final observations, the questionnaire was distributed among the respondents. A closed ended questionnaire was developed having multiple choices and the choice was given to the respondents. 


\section{DATA ANALYSIS}

2012, Vol. 2, No. 3

A significant portion of the task is the data analysis for which both descriptive and inferential techniques of Statistics have been applied. For easy understanding I have categorized the numerical information according to the nature of the question asked from the viewers.

Table 1. Attention paying to political talk shows

Contingency table $\chi^{2} \quad 2 \times 2$

$\left.(f o-f e)^{2} / f e\right)$

$\begin{array}{cccc} & \text { A lot } & \text { somewhat } \\ \text { Little } & 89 & 107 \\ & 83.89 & 112.11\end{array}$

Not at all

18

36

$23.11 \quad 30.89$

Result of Contingency table $\chi^{2} \quad$ (table 1.2) have been shown that political talk shows were credible. The viewers of these talk shows opined in favor. P-value was $=0.112$ which showed the trueness of null hypothesis. It can be concluded that the voters were politically oriented.

\section{Table 1.2: watching politics on TV}

Contingency table $\chi^{2} \quad 3 \times 2$

$\mathrm{H}_{\mathrm{o}} \quad$ Chi-square probability interest in politics and talk to friends is significant

$\mathrm{H}_{\mathrm{a}}$ Chi-square probability is not significant

$\begin{array}{ccc} & \text { Interest in politics } & \text { Talk to } \\ * 1 & 105 & 62 \\ & 92.70 & 74.30 \\ & & \\ * 2 & 111 & 126 \\ & 131.56 & 105.44 \\ & & \\ * 3 & 46 & 22 \\ & 37.75 & 30.25\end{array}$

$* 1$ indicates very much and often $* 2$ stands for somewhat and *3 shows little and never. Result revealed that people taking interest in politics. Viewers also talk to friends regarding elections. The result illustrated that $\mathrm{P}$-value $=0.001$ and null hypothesis is accepted.

\section{1: Political opinion that support statements against war on terror}

Analysis of variance in table 4.8 prescribes that the $\mathrm{SS}=15070 \mathrm{MS}=0 \mathrm{~F}$ - distribution is 0.000 . The quoting of opinion $\mathrm{M}=62.50 \mathrm{SD}=50.89$ while opinion against war on terror $\mathrm{M}=62.50$ $\mathrm{SD}=49.33$. $\mathrm{P}$ - Value is not significant 1.000 at alpha 0.05 and as result does not support the assumption that political opinion support statements against war on terrorism. 
Table 2. TV Creates political awareness

Contingency table $\chi^{2} \quad 2 \times 2$

\begin{tabular}{ccc}
\multicolumn{2}{c}{ Political awareness } & hidden agenda \\
Yes & 238 & 182 \\
& 210.00 & 210.00 \\
& & \\
No & 12 & 68 \\
& 40.00 & 40.00
\end{tabular}

Finding of chi-Sq showed that political awareness and anchors' hidden agenda both were significant because of the P-Value $=0.000$. The null hypothesis is found true. It seems that anchors always intentionally disclose the hidden agenda accordingly and the public become aware of the fact.

Table 3. Media impartiality

$\mathrm{H}_{\mathrm{o}} \quad$ Media is significantly impartial

$\mathrm{H}_{\mathrm{a}}$ Media is not significantly impartial

\begin{tabular}{lrrrrr} 
Source & DF & \multicolumn{1}{l}{ SS } & MS & F & P \\
Factor & 9 & 2250 & 250 & 0.12 & 0.999 \\
Error & 30 & 60854 & 2028 & & \\
Total & 39 & 63104 & & &
\end{tabular}

Analysis of Variance have shown that $\mathrm{SS}=2250 \mathrm{MS}=250$ and F-.12. We have already set a significant test statistics at 0.05 as alpha and the calculated P-value is 0.999 . The result of ANOVA can't support the null hypothesis. Media was not found impartial.

Terrorism $\mathrm{M}=62.5 \mathrm{SD}=59.9639$ Crime $\mathrm{M}=62.5 \quad \mathrm{SD}=54.1141$ corruption Mean= 62.5 $\mathrm{SD}=55.0182$ unemployment $\quad \mathrm{M}=62.5 \quad \mathrm{SD}=45.2143$ inflation $\mathrm{M}=62.5 \quad \mathrm{SD}=47.6410$ Poverty $\mathrm{M}=62.5 \quad \mathrm{SD}=34.6939$ political $\mathrm{M}=62.5$ $\mathrm{SD}=33.4913$ education $\mathrm{M}=87.5 \quad \mathrm{SD}=56.8653$ sectarianism $\quad \mathrm{M}=62.5 \quad \mathrm{SD}=15.5027$ Health $\mathrm{M}=62.5 \quad \mathrm{SD}=24.9065$.

Table 4. Factors that influence decision of costing vote (answer to all questions)

\begin{tabular}{l|l|l|l|l|l} 
& & $\begin{array}{l}\text { Cocial } \\
\text { status }\end{array}$ & Education & Income & $\begin{array}{l}\text { All the } \\
\text { above }\end{array}$ \\
\hline Social status & $\begin{array}{l}\text { Pearson } \\
\text { Correlation }\end{array}$ & 1 & .261 & .254 & .127 \\
\hline & Sig. (2-tailed) & & .832 & .836 & .919 \\
\hline & & & & &
\end{tabular}




\begin{tabular}{l|l|l|l|l|l}
\hline Education & $\begin{array}{l}\text { Pearson } \\
\text { Correlation }\end{array}$ & .261 & 1 & $\begin{array}{l}1.000(* \\
*)\end{array}$ & .991 \\
\hline & Sig. (2-tailed) & .832 & & .005 & .087 \\
\hline & & & & & \\
\hline Income & $\begin{array}{l}\text { Pearson } \\
\text { Correlation }\end{array}$ & .254 & $1.000(* *)$ & 1 & .992 \\
\hline & Sig. (2-tailed) & .836 & .005 & & .083 \\
\hline All the above & $\begin{array}{l}\text { Pearson } \\
\text { Correlation }\end{array}$ & .127 & .991 & .992 & 1 \\
\hline & Sig. (2-tailed) & .919 & .087 & .083 & \\
\hline & & & & &
\end{tabular}

The correlation has shown the factors that influence decision of costing vote. Findings of the table of correlation (Pearson) was at "social status with education" .261 significant with 2-tailed. "Education with income" falls in .254 with 2-tailed $1.000(* *)$. While "income with all the above" reveals .127as Sig. (2-tailed). The result supported the null hypothesis with ** correlation was significant at the 0.01 level (2-tailed).

\section{Conclusion \& Recommendations}

It can be seen a tremendous advancement in the field of Media in Pakistan. Until 2002 there was only one state owned television channel (PTV) in the country while now there are 83 television channels licensed by the Government of Pakistan. Until 2002, there was not a single FM Radio station but now 124 FM Radio stations are working under the license of Pakistan Electronic Media Regulatory Authority9. Twenty years ago only half dozen English and Urdu newspapers could be seen in the market but now hundreds of newspapers are available in the market among which almost two dozen newspapers can be called as International Standard newspapers. Furthermore, dozens of very high quality magazines are also available in market which attracts specific kind of audience like sports magazines, women's magazines, political journals and general interest magazines etc. In short, Pakistani media got a big development in quantity as well as quality in the last one decade.

An individual's likelihood of receiving political information is a function of cognitive engagement with politics. One can predicts that people with higher levels of interest in politics are more likely to receive information but less likely to yield to it. Cognitive engagement in politics should affect people's choices - specifically their willingness to consume political and news television programming. However, experimentalists have paid little attention to whether people attend to political information, especially given the availability of so many choices in our complex media environment. The TV channels are stronger than the other sources of information. Pakistan's' TV channels are more free from the government control than the past.

Following recommendations are: 
1. There is a need for a truly public service broadcaster which would reflect the view of the general population in a non-partisan manner that serves the interest of the public.

2. Media should be independent from the government or the ruling party and must be open for alternative views and comments.

3. It should also be independent of business or special interests and must be accountable only to the public through the national legislature.

4. For the purpose of expediency, the state-owned media should be transformed into this Public Broadcaster with the legal and policy framework which will guarantee its editorial independence.

5. The provision of adequate journalism education and trainings for Pakistani media personnel is necessary to remedy the level of political mediocrity within the mass media of the country. The need for basic training in news gathering and writing, investigative reporting and on the overall, ethical journalism is imperative judging.

6. The need for the revision of basic salaries for journalists in the country is the need of the time. Journalists make as low less than half of the minimum salary set for civil service employees by the public and private sector media.

7. Who shall watch the watch dog?' Though conducting research in this domain may not prove easy, it could go a long way in setting certain professional standard for journalists in the country. This type of research shall clear the cloudy environment.

8. This study has been conducted using only private TV channels in Pakistan that would suggest that further research could be conducted using newspapers, and radio.

\section{References}

Agbaje, A. (2005). "Political Parties \& Pressure Groups" in Anifowose, Remi \& Enemuo, Frances (eds.) Elements of Politics, Sam Iroanusi Publishers, Lagos.

Barber, Benjamin, R. (1984) Strong Democracy: Participatory Politics for a New Age,Berkeley: University of California Press, cop.

Buss, Terry F., Redburn, Stevens F. \& Guo, Kritina (Eds) (2006) Modernizing

Democracy:Innovations in Citizen Participation, Armonk, New York: M.E. Sharpe

Cammaerts, Bart (2007) "Citizenship, the Public Sphere, and Media" in

Cammaerts, Bart \& Carpentier, Nico (2007) "Participation and Media" in Cammaerts, Bart \& Carpentier, Nico (eds.) Reclaiming the Media Communication Rights and Democratic Media Role, Bristol, UK: Intellect

Clancey, M., \& M. Robinson. (1985). General Election Coverage: Part I. Public

Opinion. Washington, D.C.

Comstock, G., Chaffee, S., \& Kautzman, N. (1978). Television and human 
behavior. New York: Columbia University Press.

Delli Carpini, Michael X., and Scott Keeter. (1996). What Americans Know About Politics and Why It Matters. New Haven, CT: Yale University Press.

Gerbner, G. (1998). Cultivation analysis: An overview. Mass Communication \& Society, $l(3 / 4), 175-194$.

Gerbner, G., \& Gross, L. (1976). Living with television.:The violence profile. Journal of Communication, 26(2), 173-199.

Burton, Graeme (2005) Media and Society: Critical Perspectives, Maindenhead: Open University Press

Graber, D. (1976). Press and Television as Opinion Resources in Presidential Campaigns. Public Opinion Quarterly (New York), 1976.

Gomez, Brad T., and J. Matthew Wilson. (2001). "Political Sophistication and Economic Voting in the American Electorate: A Theory of Heterogeneous Attribution." American Journal of Political Science 45: 899-914.

Krosnick, Jon A., and Laura Brannon. (1993). "The Impact of the Gulf War on Ingredients of Presidential Evaluations:Multidimensional Effects of Political Involvement." American Political Science Review 87(4):963-975.

Konijn, E. A., Bijvank, M. N., and Bushman, B. J. (2007). I Wish I were a Worrier: The Role of Wishful Identification in the effects of Violent video games on Aggression in Adolescent boys. Developmental Psychology, 43, 1038-1044.

Kubey, R.,\&Csikszentmihalyi, M. (2002). Television addiction is no mere metaphor. Scientific American, 286, 74-80.

Louw, Eric (2005) The Media and Political Process, London: Sage

Iyengar, S., \& Kinder, D. (1987). News That Matters: Television and American Opinion . Chicago : University of Chicago Press

Iyengar, S. and McGrady, J. (2007). Media Politics. A Citizen.s Guide, New York: W. W. Norton \& Company.

Lilleker, G. Darren (2006). The Impact of Political Marketing on Internal Party Democracy. Parliamentary Affairs, 58 (3), 570-584. 
McQuail, Denis (1992) Media Performance: Mass Communication and the Public Interest, London: SAGE

McQuail, D. (2000). McQuail's Mass Communication Theory, $4^{\text {th }}$ Edition, London, Thousand Oaks, New Delhi: Sage Publications.

Miller, Joanne M., and Jon A. Krosnick. (2000). "NewsMedia Impact on the Ingredients of Presidential Evaluations: Politically Knowledgeable Citizens are Guided by a Trusted Source." American Journal of Political Science 44(2):301-315.

Maurer, T. (2009). Fernsehen - als Quelle politischer Information tiberschatzt. Eine Bestandsaufhahme des Angebots und der Nutzung des „politischen Leitmediums". From: Marcinkowski F./ Pfetsch B. (Ed.): Politik in der Mediendemokratie, Wiesbaden: VS-Verlag, pp. 129-150

Negrine, R. (1996). The Communication of Politics. London: SAGE

Norris, P. (2000). A Virtuous Circle. Political Communication in Postindustrial Societies. Cambridge: Cambridge University Press

Petersson, Hemes, Holmberg, Togeby and Wagnerud (2000). Demokrati utan partier? Demokratiradets rapport 2000, SNS Forlag, Stockholm.

Price. Vincent, and John Zaller. (1993). "Who Gets the News? Alternative Measures of News Reception and Their Implications for Research." Public Opinion Quarterly 57(2): 133-164.

Strohmeier,G. (2004). Politik und Massenmedien. Eine Einfuhrung, BadenBaden: Nomos-Verlag

Timberg, B. (2002). Television talk: A history of the TV talk show. Austin, TX: University of Texas Press.

Zaharopoulos, T. (2001). Traditional Family Relationships and Television Viewing in Greece: TBS Archieves,6.

Zaller. John R. (1989). "Bringing Converse Back In: Modeling Information Flow in Political Campaigns." Political Analysis 1(1):181-234. 